\title{
Middeleeuse Studies, Mediëvalistiek en Mediëvalisme: Kritiese onderskeide en samehange
}

Author:
Johann Beukes ${ }^{1}$
Affiliation:
'Department of Philosophy
and Classics, Faculty of
Humanities, University of the
Free State, Bloemfontein,
South Africa
Corresponding author:
Johann Beukes,
johannbeukes@icloud.com
Dates:
Received: 08 Mar. 2021
Accepted: 20 Apr. 2021
Published: 28 June 2021
How to cite this article:
Beukes, J., 2021,
'Middeleeuse Studies,
Mediëvalistiek en
Mediëvalisme: Kritiese
onderskeide en samehange',
mobite device
to read online.
Verbum et Ecclesia $42(1)$,
a2236. https://doi.
org/10.4102/ve.v42i1.2236
Copyright:
Co 2021. The Authors.
Licensee: AOSIS. This work
is licensed under the
Creative Commons
Attribution License.

Medieval Studies, Medievalist Studies and Medievalism: Critical distinctions and intersections. The aim of this article is to clarify Medievalism (Mediëvalisme) as a research challenge in Medieval Studies, thereby contributing to the discipline's methodological and contemporary-discursive development. In conjunction with the author's recent analyses of three subject-internal problems in Medieval philosophy ([1]the calibration of periodisation; [2] latent Orientalism and the subsequent problem of 'two registers' ['East' and 'West']; as well as [3] the problem of the 'canon'), Medievalism is presented as the idea-historical postulation of a Medieval 'Other' with the subtle intent to alleviate the notion of some contemporaneous 'Self'; in other words, Medievalism points toward the apparent spontaneous acceptance of a disparity between a superior post-Medieval Self and an inferior Medieval Other. This includes the essentialising of a single aspect, or contingent aspects, of the Medieval Other, which results in conjectures of deeply caricaturised and quasi-comprehensive views of the Middle Ages. Medievalist Studies (translated for the sake of clarity, as Mediëvalistiek in Afrikaans to circumvent the curious and confusing overlapping of the terms 'Medievalist Studies' and 'Medievalism' in English), the discipline that studies the post-Medieval reception of the Middle Ages (in whatever form or genre), is presented as a legitimate supplementary tool for exposing Medievalism, particularly in non-specialised contexts. The article henceforth argues for the systematic employment of Mediëvalistiek in its countering of Mediëvalisme as an effective supplementary resource in MedievalStudies - especially within the context of the contemporary Neoconservative reception of the Middle Ages.

Intradisciplinary and/or interdisciplinary implications: Dealing with a millennium-long variety of discourses, Medieval Studies functions in a Venn-diagrammatical relationship with Medieval philosophy, Medieval history, church history, patristics, philosophy of religion and sociology of religion. Whenever these proximate disciplines are impacted by specialist Medieval research, it may well have noteworthy implications. Such is the case in this critical distinction between and clarification of the intersections between Medieval Studies, Mediëvalisme (Medievalism) and Mediëvalistiek (Medievalist Studies).

Keywords: Methodology in Medieval scholarship; MedievalStudies; Medievalism, Medievalist Studies; Mediëvalisme; Mediëvalistiek; Neoconservatism; Neomedievalism.

\section{Mediëvalisme en Mediëvalistiek: Probleemstelling en begripverheldering}

Die oogmerk van hierdie artikel is om Mediëvalisme as 'n unieke navorsingsprobleem in Middeleeuse Studies te omskryf en te ontleed. Deur kritiese onderskeide tussen Middeleeuse Studies, Mediëvalistiek en Mediëvalisme te tref en hulle samehange uit te wys, lewer die artikel 'n bydrae tot die metodologiese verantwoording en diskursiewe ontwikkeling binne die toepaslike dissiplines in eietydse Middeleeuse Studies. Aangesien dít wat binne ideëhistoriese konteks deur die begrippe Mediëvalistiek en Mediëvalisme aangedui word, steeds onverken is in Afrikaans, word die twee begrippe neologisties aangebied deur dit onveranderd uit die Nederlandse taalregister oor te neem met die oog op die gelykmatige opname daarvan in die Afrikaanse vakregister.

Middeleeuse Studies sluit alle dissiplines in wat gespesialiseerd en hoofsaaklik met die vertaling, ontleding en kritiese kommentariëring van tekste tussen ongeveer die vroeë vyfde tot die middelvyftiende eeue besig is. Dit sluit in, onder meer, Middeleeuse argitektuur, geskiedenis, filosofie, kuns, musikologie, sosiologie, teologie, manuskripredigering en gespesialiseerde vertalings van 
Middeleeuse tekste in alle tersaaklike tale, onder meer (Middeleeuse) Latyn, Arabies, Hebreeus, Grieks, Middel(Hoog-)duits, Middelnederlands, Middelengels en Oud-Frans.

Mediëvalistiek dui op 'n betreklik onlangse ${ }^{1}$ ontwikkeling binne die vakraamwerk van Middeleeuse Studies wat uitsluitlik gerig is op die genre-onafhanklike ontleding van post-Middeleeuse interpretasies van die Middeleeue. Mediëvalistiek is dus die studie van ná-vyftiende-eeuse interpretasies van die Middeleeue, ongeag vorm of genre (Biddick 1998:1-11; Prendergast \& Trigg 2009:117).

Mediëvalisme dui op post-Middeleeuse, ideologies reduksionistiese en anachronistiese herkonstruksies van die Middeleeue, waarvolgens die Middeleeue deur die essensialisering van een of meer kontingente (of onnoodsaaklike toevallighede) met gevolglike karikaturisering en geheelaanspraak aangebied word. In verruimende aansluiting by die skrywer se onlangse drieledige toeligting (cf. Beukes 2020a:3;12-14, 2020b:1-6, 2021a:1-6) van die huidige navorsingsuitdagings in die dissipline Middeleeuse Filosofie (ten opsigte van [1] die probleem van die standaardisering en interne periodisering van Middeleeuse filosofie, [2] die probleem van 'n latente Oriëntalisme en gevolglik 'twee registers' ['Wes' en 'Oos'] en [3] die probleem van die 'kanon' in die Middeleeuse ideëgeskiedenis), word Mediëvalisme hier aangebied as die post-Middeleeuse opstelling van 'n Middeleeuse 'Ander' ter wille van die bestendiging van 'n eietydse 'Self'. Anders gestel, Mediëvalisme dui op die skynbaar spontane postulering van 'n dispariteit tussen 'n meerderwaardige tydgenootlike Self en 'n ondergeskikte Middeleeuse Ander. Mediëvalisme is in die retrospektiewe (en per definisie anachronistiese) aard daarvan dinamies en wisselend: die soort Mediëvalismes wat in die Renaissance aangetref word, verskil dus van die variante daarvan in vroeë, hoë en laat moderniteit. ${ }^{2}$ In elkeen van hierdie periodes vind 'n unieke verselfstandiging van toevallige elemente in die Middeleeuse ideë- en institusiegeskiedenis plaas, op grond waarvan 'n idiosinkratiese (dikwels volslae foutiewe) beeld van die Middeleeue gepostuleer word. Pejoratiewe, patroniserende en inderdaad vals karikature van die Middeleeue (na 'n tipiese Renaissancistiese Mediëvalisme, byvoorbeeld 'in die middel', 'donker' en 'wreed', of na 'n tipiese 19de-eeuse Mediëvalisme, byvoorbeeld 'eerliker', 'meer ridderlik', 'meer maagdelik' en 'geestelik boetvaardiger') gaan telkens terug na die een of ander onverantwoorde Mediëvalistiese lengtesnit (cf. Roden 2001:115-130).

Ongelukkig word die begrippe Mediëvalisme en Mediëvalistiek nie koherent in die Engelse taal onderskei

1.Biddick (1998:1-25) vind egter in haar epogmakende werk (The shock of Medievalism, 1998) die diskursiewe spore van Mediëvalistiek reeds sover terug soos die 19de eeu. In haar ondersoek na die ontwikkeling van sowel Middeleeuse Studies as Mediëvalistiek, betoog sy oortuigend dat Middeleeuse Studies sigself vanaf die laat-19de eeu tot in die laat-1960's toenemend deur 'n proses van isolasie en uitsluiting gedefinieer het, ingevolge dit wat nie aan daardie (selfopgestelde) rigiede kriteria vir (hoo modernistiese) wetenskaplikheid voldoen het nie radikaa kriteria vir (hoog modernistiese) wetenskaplikheid voldoen het nie, radikaa van die 19de eeu enige 'populêre' of nie-gespesialiseerde interpretasies van die Middeleeue ingesluit.

2.Die gebruik van die ambivalente begrip postmoderniteit word vermy en voorkeur word verleen aan die begrip laat moderniteit. Vir die verantwoording, sien Beukes (2020c:1-11). nie. Daar bestaan naamlik in Engels 'n begripverwarring wat geskep is deurdat hierdie twee verwante, maar verskillende begrippe - Mediëvalisme (Medievalism) en Mediëvalistiek (Medievalist Studies) - vermeng geraak het. Ook in Engels bestaan die drie onderskeibare begrippe: Medieval Studies (wat dus alle dissiplines insluit wat die Middeleeue gespesialiseerd bestudeer), Medievalist Studies (dus die studie van post-Middeleeuse interpretasies van die Middeleeue) en Medievalism (die ideologiese en reduksionistiese verskynsel Mediëvalisme, soos bostaande toegelig). Die probleem is dat Medievalist Studies en Medievalism as uitruilbare begrippe en selfs as sinonieme in Engels funksioneer - juis omdat Medievalist Studies met die ontwikkeling van die deeldissipline in die vroeë 1970's eenvoudig Medievalism genoem is.

Die rede daarvoor was vakkundig elitisties: Normaalweg word ' $n$ opkomende akademiese vakgebied immers nie met die -isme-agtervoegsel ontwikkel en aangebied nie, maar met (in Afrikaans) -logie (in Engels -logy) of, skerper Diets, -istiek (in Engels -istics). Met Mediëvalistiek en Mediëvalisme was dit kennelik nie die geval nie: Mediëvalistiek of Medievalist Studies as die studie van postMiddeleeuse interpretasies van die Middeleeue (en dus nie studie van die Middeleeue as sodanig nie) is as 'n tweederangse parodie en 'n tweedeliniese, onoutentieke en ideologiese ontwikkeling beskou - en as sodanig met 'n -isme benoem - synde Medievalism.

In stede daarvan om die vestiging van Mediëvalistiek (dus Medievalist Studies) juis as ' $n$ ideologies kritiese bydrae vanuit ontwikkelinge in die filosofiese hermeneutiek in die tweede helfte van die 20ste eeu te herken, is Mediëvalistiek as ideologiese swendelary in die groter veld van Middeleeuse Studies (Medieval Studies) gekenmerk. Dit het heelwat tyd geneem om die aanvanklik verkleinerende benaming Medievalism te vervang met Medievalist Studies. Die destydse vooroordeel bly egter hardnekkig aanwesig en lei steeds tot erge semantiese verwarring - wanneer die vernaamste ideologiese teiken van Medievalist Studies, naamlik Medievalism, steeds gebruik word om na Medievalist Studies self te verwys. ${ }^{3}$

Die oplossing vir hierdie problematiese begripoorvleueling in Engels is nougesette konsekwentheid: afgesien van die vanselfsprekende aandrang dat Medievalist Studies en Medievalism in Engelse publikasies rigied uit mekaar gehou behoort te word (wat nie gebeur nie), behoort publikasies in ander tale vakterminologiese dissipline aan die dag te lê deur ontwikkeling van die vaktaal wat die twee begrippe duidelik van mekaar onderskei - ook al beteken dit dat neologismes

3. Hierdie knaende elitisme blyk byvoorbeeld uit die redaksionele beleid van talle vooraanstaande vaktydskrifte in Middeleeuse filosofie wat steeds nie manuskripte vir portuurevaluering oorweeg wat handel oor post-Middeleeuse resepsies van die Middeleeue nie (dit wil sê Mediëvalistiek), maar slegs voorleggings wat handel oor 'die Middeleeue as sodanig' (dit wil sê Middeleeuse Studies). Presies waarom nie die Middeleeue as sodanig (dit wil sê Middeleeuse Studies). Presies waarom nie ingesien word dat enige post-Middeleeuse ontleding en interpretasie van ' $n$ Middeleeuse teks of kwessie altyd ' $n$ herkonstruksie is (juis ook met betrekking to gespesialiseerde uitsette in Middeleeuse Studies), val die skrywer op as filosofie diep teenstellend en hermeneuties bedenklik. Die Middeleeue kan nie los bedin word van enige tydgenootlike interpretasie daarvan nie. In daardie $\sin$ is die Middeleeue 'in elke opvolgende post-Middeleeuse geslag se hande' (Petersen 2011:36) 
op die spoor van moedertale of verwante tale geskep moet word. ${ }^{4}$ Daarom word die begrippe Mediëvalisme en Mediëvalistiek hier op Nederlandse spoor in die Afrikaanse taal met duidelike onderskeiding aangebied.

\section{Middeleeuse Studies en Mediëvalistiek: Kritiese onderskeide en samehange}

Onderstaande word betoog dat Mediëvalistiek eietyds binne die vakraamwerk van Middeleeuse Studies aanvaar behoort te word as ' $n$ belangrike aanvullende instrument om Mediëvalisme te ontmasker as die reduksionistiese, anachronistiese en ideologiese verskynsel wat dit ten diepste is. Met die vestiging van Mediëvalistiek as dissipline in die vroeë 1970's is dit egter van meet af aan 'n sekondêre ontwikkeling geag: 'n minderwaardigheid, by verre ondergeskik aan en trouens in die 'ghetto' 5 van Middeleeuse Studies, wat niks meer te bied het nie as die identifisering en ontleding van problematiese interpretasies en wanvoorstellinge van die Middeleeue. Middeleeuse Studies is daarom spontaan as die 'oorspronklike' dissipline gehandhaaf en gereserveer vir slegs eersterangse en gespesialiseerde navorsingsuitsette in Middeleeuse dissiplines, terwyl Mediëvalistiek as 'n tweederangse afdruk, swak nabootsing en bedenklike parodie van Middeleeuse Studies aangebied is. ${ }^{6}$

Hierdie inhiberende en modernistiese vakvooroordeel moet veral eietyds teengegaan word. Afgesien van (1) die epistemologiese kompleksiteit verbonde aan die verhouding tussen primêre tekste (in hierdie geval, Middeleeuse Studies) en sekondêre tekste (hier Mediëvalistiek), asook die hermeneutiese draagwydte van die diskursiewe potensiaal opgesluit in laasgenoemde, moet (2) van meet af toegegee word dat die begrip Middeleeue vanweë die histories gekonsentreerde geladenheid daarvan niks meer as 'n verleentheidsuitweg is nie (Beukes 2020a:I:1-3). Die Middeleeue (selde 'n neutrale begrip) dui immers op heterogene spektra van diverse kulturele, maatskaplike, godsdienstige, demografiese, etniese, linguistiese en ekonomiese ontwikkelinge oor 'n tydperk van meer as ' $n$ duisend jaar. ${ }^{7}$ Daarby (3) is die konseptuele verhouding

4.In terme van bronnehantering en aanhalings vanuit Engelse tekste word daarop gewys dat waar hierdie begripoorvleueling in daardie bronne voorkom en die begrip Medievalism gebruik word om inderdaad da Medievalist Studies te verwys, die skrywer in Afrikaans die onderskeid uitdruklik handhaaf in die begrippe Mediëvalisme en Mediëvalistiek.

5.Vergelyk die historiese uiteensetting van Aers (1992:24-25) van die vestiging en

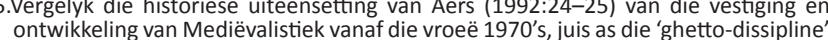
ontwikkeling van Mediëvalistie
van Middeleeuse Studies.

6.Die skrywer is nie bewus van ' $n$ filosofiedepartement in Suid-Afrika wat voorsiening maak vir Mediëvalistiek in die kurrikulum nie.

7.Vir ' $n$ oorsig van die skrywer se datering van die ideëhistoriese raamwerk van die Middeleeue (410-1464) en sesledige interne periodisering van die Middeleeuse filosofiegeskiedenis (met betrekking tot die post-Romeinse [410-742]; Karolingiese [742-877]; post-Karolingiese [877-1088]; vroeë skolastiese [1088-1225]; hoë skolastiese [1225-1349]; en postskolastiese [1349-1464] periodes), sien Beukes (2020a:l:12-14). Vir 'n uitgebreide verantwoording van die aanmerking uit die 'postskol:12-14), Vir ' $\mathrm{n}$ uitgebreide verantwoording van die aanmerking uit die postskolastiese' periode as sodanig, sien Beukes (2021a:1-11). Ingevolge hierdie datering en interne periodisering sou die eerste drie periodes (dus 410-1088) oo as die 'vroeë Middeleeue', die twee skolastiese periodes (dus 1088-1349) ook as die 'sentrale Middeleeue, en die laaste periode (1349-1464) ook as die 'later Middeleeue bekend kon staan. Hierdie datering en interne periodisering is ' poging om die meer as ' $n$ duisend jaar wat deur die heterogene 'Middeleeue' bestryk word, minstens in genuanseerde periodes in te deel. tussen die Middeleeue en moderniteit, bemiddel deur die Italiaanse Renaissance, dinamies en voortdurend onderworpe aan wysiging en verandering, juis wanneer die Middeleeue vanuit welke tydgenootlike konteks ook al opgeroep word. Ook (4) verwys die begrip Middeleeue ' $n$ geruime tyd al nie meer na 'n uitsluitlik Latyns-Westerse konteks nie: die aanspraak van, onder meer, die 'Middeleeuse Oosterse Ander' (Beukes 2018a, 2018b) en die toepaslikheid van die begrip Middeleeue op historiese periodes en ontwikkelinge in nieEuropese konteks tussen die vyfde en vyftiende eeue, staan eietyds voorop in Middeleeuse spesialisnavorsing (Beukes 2020c:11-12). Is die onderskikking van Mediëvalistiek aan Middeleeuse Studies teen hierdie vierdelige dekorstelling nog geregverdig? Skerper gevra: behoort Middeleeuse Studies eietyds nie deur Mediëvalistiek neweskikkend aangevul te word, juis om die 'oorspronklike' of 'outentieke' en die 'afdruk of 'nie-outentieke' van mekaar te onderskei nie?

Een van die diskursiewe voordele van Mediëvalistiek is, na die betoog van een van hierdie sywaartse dissipline se eerste eksponente, Umberto Eco (1986:59-65; cf. Prendergast \& Trigg 2009:118), die genre-soepelheid daarvan (synde 'n 20steeeuse dissipline wat uitsluitlik op post-Middeleeuse interpretasies en resepsies van die Middeleeue gerig is): Eco se bekende uiteensetting van die tien wyses waarop die Middeleeue in die laat moderne tyd 'gedroom' kan word, beweeg onproblematies tussen filologie (en sy spesialisveld, semiotiek), rolprentnarratiewe en kinematografie, fiksie ${ }^{8}$ en 'n verskeidenheid ander populêr kulturele genres en vorme. Eco (1986:65-80) betoog subtiel dat beide Middeleeuse Studies (byvoorbeeld via filologie en semiotiek) en Mediëvalistiek (byvoorbeeld via film en fiksie) ' $n$ bydrae lewer tot 'n eietydse konseptualisering van die Middeleeue.

Eco se standpunt kan met simpatieke instemming aanvaar word. Die onderskeid tussen Middeleeuse Studies en Mediëvalistiek behoort egter behoue te bly: die een kan nie resloos in die ander opgeneem word nie. Die rede daarvoor is dat Mediëvalistiek juis nié 'n bydrae kan lewer tot die gespesialiseerde eksegese (ingesluit filologies en semioties) van Middeleeuse tekste nie. Daar is aspekte van Middeleeuse navorsing wat so gespesialiseerd is dat dit slegs deur vakkundiges wat behoorlik in die dissipline onderlê is, onderneem kan word: dit geld, onder meer, vir manuskripredigering ${ }^{9}$, tekskritiese redigering en die vertaling

8.Eco se debuutroman The Name of the Rose (1980) bied waarskynlik een van die mees treffende voorbeelde van die Mediëvalistieke (in geen opsig'n Mediëvalistiese nie) wyse waarop die Middeleeue vanuit 'n bepaalde eietydse konteks 'gedroom' nie) wyse
kan word.

9.'n Goeie voorbeeld is die herredigering en hersamestelling van Herrada Landsbergensis ('van Hohenbourg', ca.1130-1191) se Hortus Deliciarum (ca.1185) in 1979 (Beukes 2021b:3-5): Die oorspronklike manuskrip (tesame met die slegs een behoue en volledige afskrif daarvan) het verlore gegaan in die Frans-Pruisiese oorlog (1870) ná die bombardering van Straatsburg in Augustus van daardie jaar. Met slegs onvolledige afskrifte van die manuskrip wat wel behoue gebly het, is ' $n$ omvangryke inisiatief in die middel-1970's van stapel gestuur om die Hortus so volledig moontlik te herkonstrueer. Met 19de-eeuse transkripsies van gedrukte weergawes van die onvolledige afskrifte as basis vir die herkonstruksie van die verlore manuskrip, het Rosalie Green, Direkteur van die Index of Christian Art by verlore manuskrip, het Rosalie Green, Direkteur van die Index of Christian Art by Princeton Universiteit, die leiding geneem met ' $n$ herplasing van meer as 1160 teksgedeeltes en vergelykende illustrasies, asook ' $n$ katalogisering van meer as 340 miniatuursketse en volblad-illustrasies. In 1979 is die manjifieke herkonstruksie van Hortus Deliciarum in twee volumes deur Brill in Leiden as ' $\mathrm{n}$ projek van die Warbur Institute in Londen (met die projektitel Studies of the Warburg Institute XXXVI) gepubliseer: Die eerste volume bestryk kommentaar op die manuskrip en verantwoording vir die projek as sodanig (reds. Green et al. 1979a). Die tweede 
van Middeleeuse Latyn en Arabies in eietydse tale, ${ }^{10}$ asook Middeleeuse trajeknavorsing. ${ }^{11}$ Mediëvalistiek is dus nie in staat om betekenisvolle eksegetiese bydraes te lewer nie.

Mediëvalistiek beskik wel oor die vermoë om te kan aandui wanneer ' $n$ voorstelling of lesing eisegeties is: in hierdie opsig vestig Mediëvalistiek se vermoë eerder daarin om anachronismes, historiese foute en veral stemminge wat met sosiale stratifisering geassosieer word, binne uiteenlopende institusionele en maatskaplike kontekste uit te wys. Mediëvalistiek se - wat nou verantwoord genoem kan word - ideologiekritiese vermoë kan dus as aanvullend tot Middeleeuse Studies gestel word, sonder om dit ondergeskik aan Middeleeuse Studies te stel.

Daar is wel ' $n$ uitdruklik histories-kritiese element in hierdie veronderstelde ideologiekritiese vermoë van Mediëvalistiek aanwesig, wat in eietydse gedaante teruggaan na die aanvegting van moderne historisme. Teen die historistiese enkelgreep op die geskiedenis - naamlik teleologiese ontwikkeling met 'n streng opwaartse kurwe - bied Mediëvalistiek vanuit die soepele aard daarvan 'n wydgaande register van moontlike antwoorde op ' $n$ gefragmenteerde verlede wat so ' $n$ teleologie (die hele verlede in opmars na ' $n$ historiese voleinding) krities teengaan. Hierdie historieskritiese reaksies vanuit Mediëvalistiek (byvoorbeeld via film of fiksie, juis na 'n teks en die rolprentverwerking daarvan soos dié van Eco se The name of the rose [1980] sou natuurlik steeds deur elitiste in MiddeleeuseStudies as 'minderwaardig', 'populisties' en 'nie-akademies' getipeer word: so 'n puristiese teenwerping sou daarop aanspraak maak dat Mediëvalistiek eerder deur nostalgie, utopie, distopie en fantasie as deur hardekern-analises bepaal word. Tog word vanuit Mediëvalistiek historiserende antwoorde oor die Middeleeue gebied wat wel geldig is of kan wees - en vanuit die genresoepelheid daarvan teleologiese interpretasies skerp kan teengaan. Juis omdat Mediëvalistiek nie hoef te konformeer aan konvensionele historiese en historiografiese konvensies nie (nogeens per aanbod van byvoorbeeld film of fiksie), kan dit die register waaruit die Middeleeue telkens en opnuut herlees word, hermeneuties en juis histories-krities verryk.

Binne hierdie verruimende en kreatief historiserende konteks van die Middeleeue, as sodanig, kan verwys word (weer met inagneming van sowel die tekste as rolprentverwerkings) na J.R.R. Tolkien ([1954] 2014) se The Lord of the Rings in drie volumes en C.S. Lewis (1950-1956) se The Chronicles of Narnia in

\section{(voetnota 9 kontinueer...)}

volume bevat die keurig gerekonstrueerde manuskrip (reds. Green et al. 1979b). Manuskripredigering en tekskritiese rehabilitasie van hierdie aard kan op geen ander plek en wyse as vanuit buitengewoon gespesialiseerde vakruimtes in Middeleeuse Studies onderneem word nie. Mediëvalistiek kan hiertoe geen bydrae lewer nie.

10.Vergelyk byvoorbeeld die vertaling van die primêre tekste van Alkindi, die 'eerste Arabiese filosoof', deur P. Adamson en P. Pormann ([reds. \& vertalers] 2012:3-338 die eerste vertaling van Alkindi se werke uit Arabies in Engels, op grond van 24 redaksionele temas). Mediëvalistiek kan ook, binne hierdie soort gespesialiseerde vertalingskonteks, geen bydrae lewer nie.

11.Vergelyk byvoorbeeld die skrywer (Beukes 2021c:1-8) se herkonstruksie van Neoplatonisme in die Dominikaanse Keulen-tradisie van die latere Middeleeue. Hierdie soort trajeknavorsing, wat poog om ideëhistoriese ontwikkelinge oor meer as 800 jaar koherent byeen te bring, verg tegniese, analitiese en linguistiese vaardighede op 'n vlak waartoe Mediëvalistiek geen betekenisvolle, verruimende en kritiese bydrae kan lewer nie. Slegs 'n outentieke vakkenner in Middeleeuse Studies (in hierdie geval, in Middeleeuse Filosofie) sou die uitkoms van so 'n Studies (in hierdie geval, in Middeleeuse Filosofie) sou die uitk
trajekanalise krities kon evalueer en as geldig of ongeldig aandui. sewe volumes. Die vraag is: ook al sou hier geen sprake van 'n gespesialiseerde analise van die Middeleeue of Middeleeuse temas aanwesig wees nie, sou hierdie magistrale fiksies nie oor die potensiaal beskik om wel tot 'n tydgenootlike herverstaan van die Middeleeue by te dra en bestaande en historiese Mediëvalismes te konfronteer nie? By Tolkien en Lewis se gevierde verhale kan byvoorbeeld ook die uitsonderlike aanbod The Pillars of the Earth van die Walliese skrywer Follett (1989) vermeld word, as 'n uitstekende voorbeeld van grondige navorsing deur ' $n$ nie-spesialis waarin 'n digte narratief beskikaar gestel word waardeur Middeleeuse argitektuur, kerkgeskiedenis en filosofie intiem verweef is. Volgens die uitgewer is meer as 27 miljoen eksemplare van die boek verkoop. ${ }^{12}$ Meer onlangs vertoon die televisiereeks Game of Thrones, in agt seisoene en 73 episodes (HBO 2011-2019), gebaseer op die fiksiereeks A Song of Ice and Fire, in vyf volumes, deur G.R.R. Martin (1996-2011), prominent in die aanbod van die verhouding tussen eklektiese, nie-gespesialiseerde navorsing en 'n aweregse verhaal oor 'n epog wat die Middeleeue kennelik naboots. Teen die sesde seisoen het die gemiddelde kykertal van Game of Thrones 25 miljoen per episode beloop (Shepherd 2016:1), terwyl die vyf volumes van A Song of Ice and Fire in 47 tale vertaal en reeds meer as 90 miljoen eksemplare verkoop het (Shepherd 2016:1). 'n Beweging tussen genres - en nie gespesialiseerde analises alleen nie - speel duidelik 'n rol om post-Middeleeuse interpretasies van die Middeleeue tydgenootlik beskikbaar te stel en beskik oor die vermoë om dit wel ook histories verantwoord te kan doen. Dit beteken nie' $n$ konformering van feite aan fiksie nie. Dit beteken bloot dat fiksie ook feitelik korrek en histories verruimend kan funksioneer, die teleologie van moderne historisme kan teengaan en (ironies) hermeneutiese ontwikkeling in Middeleeuse Studies kan stimuleer.

Die onmiddellike vraag is: watter spesialisuitset in Middeleeuse Studies annekseer die aandag van 27 miljoen lesers en 25 miljoen kykers (per week)? Geen uitset nie, natuurlik. Maar dan is die onmiddellike en geldige teenvraag - en dit is waar die legitieme ideologiekritiese aanspraak van Mediëvalistiek sigself aanbied: is hierdie enorme resepsiegetalle nie presies die risiko verbonde aan moontlike en selfs onafwendbare wanvoorstellinge wat in nie-gespesialiseerde aanbiedinge opgesluit lê nie? Indien 'n Middeleeuse spesialis binne 'n vakkundige netwerk van, argumentshalwe, 50 internasionale spesialiste 'n wanvoorstelling per manuskripaanbod sou maak, word dit normaalweg gou deur die netwerk gekorrigeer deur middel van portuurevaluering, ruim voor publikasie. Ook al sou die netwerk en algemene spesialisnavorsing in gebreke bly om die wanvoorstelling onmiddellik te identifiseer, sal aangedring word op korreksies binne die afsienbare toekoms ná publikasie - of dit sal, met groot verleentheid, namens die skrywer gedoen word. Maar wie dring aan op korreksies wanneer wanvoorstellinge voorkom per disseminasie na miljoene, op grond van 'n enkele teks, of selfs een aanbod na miljoene per uitsending van 'n enkele uur? ${ }^{13}$

12.https://www.panmacmillan.com.au/9781760981112/ - geraadpleeg op 14 Desember 2020

13.Vir ' $n$ oorsig van die wyse waarop massa-disseminasie in die digitale era Mediëvalistiek self impakteer (en Mediëvalistiek reeds tot 'n 21ste-eeuse soort 'Neomediëvalistiek' omvorm het), sien Fitzpatrick (2011:11-20) 
In die mediagedrewe aard van die eietydse disseminasie van 'inligting', lewer ingeligte vakgebaseerde ideologiekritiek 'n onmisbare bydrae deur wanvoorstellinge, asook versluierde feitefoute, ten opsigte van, onder meer, ideëhistoriese periodes uit te wys. Binne die historiese konteks van die Middeleeue behoort hierdie korrigerende taakstelling Mediëvalistiek toe te val. ${ }^{14}$ Middeleeuse Studies gaan dié dringende korreksies nie aanspreek of aanbring nie: dit val eenvoudig buite die raamwerk van wat Middeleeuse spesialiste (om verstaanbare redes) as hulle vakbepaalde werkruimte sou beskou. Die probleem is egter dat idees oor die Middeleeue progressief nie deur Middeleeuse spesialiste gevorm word nie, maar juis deur eksponente van genres wat sydelings en nie-gespesialiseerd by die Middeleeue aansluiting vind. Wat by verre die meerderheid mense in die derde dekade van die 21ste eeu oor die Middeleeue weet, of dink hulle weet, het hulle waarskynlik geleer by Game of Thrones - of ten beste by 'n ingegrawe romansier soos Follett. Indien daardie kennis op growwe wanvoorstellinge berus, is daar geen portuurevaluasie of interne vakdinamika om verdere disinformasie tot nadeel van Middeleeuse Studies en die Middeleeue self te verhoed nie.

Juis hier kan Mediëvalistiek se sonderlinge nis aangedui word in die ideologiekritiese verrekening van die spanningsvolle ruimte tussen spesialisnavorsing en niegespesialiseerde, post-Middeleeuse interpretasies van die Middeleeue. Mediëvalistiek se taak is om uit te wys wat die Middeleeue nie is nie, eerder as om betoë te lewer vir wat dit wel is, of sou kon wees. Ten einde wanvoorstellinge in terme van anachronismes, feitefoute, vertalingsfoute en kulturele, geografiese en etniese misplasings uit te wys en teen te gaan, is Mediëvalistiek aangewese op die primêre korrektiewe bron, te wete Middeleeuse Studies. Om postMiddeleeuse (normaalweg lengtesnit-) interpretasies van die Middeleeue te evalueer, word dus en ineens vooronderstel 'n kennis van die Middeleeue per geëvalueerde (normaalweg dwarssnit-) analises (via Middeleeuse Studies). Mediëvalistiek moet dus vakkundig grondig toegerus wees om ideologiekrities binne welke post-Middeleeuse tydgenootlike konteks ook al effektief te kan funksioneer. Daarom behoort Mediëvalistiek self by geleentheid in staat te wees om spontaan aan die eietydse spesialisdiskoers oor die Middeleeue deel te neem, onder meer, deur die lesings en resepsie van gevestigde eietydse filosowe van die Middeleeue krities te evalueer. ${ }^{15}$ Dit veronderstel dat Mediëvalistiek dubbel ingelig sal wees, sowel deeglik op hoogte van die

14. Hoewel die skrywer nie formeel ' $\mathrm{n}$ eksponent van Mediëvalistiek is nie en binne Middeleeuse Studies as sodanig werk, is hy daarvan oortuig dat die verdediging van die legitimiteit van Mediëvalistiek se aanvullende bydrae tot Middeleeuse Studies nie vanuit Mediëvalistiek onderneem behoort te word nie, maar vanuit Studies nie vanuit Mediëvali
Middeleeuse Studies self.

15.Vergelyk byvoorbeeld die hoogs tegniese bydraes in die identifisering van unieke Mediëvalismes in die psigoanalises van Jacques Lacan vanuit ' $n$ uitdruklik Mediëvalistieke oriëntasie, deur Labbie (2006:1-45) en Ingham (2009:17-20). Daarby bestaan ' $n$ veeltal Mediëvalistieke evaluasies van Michel Foucault se resepsie van die Middeleeue en Middeleeuse temas: vergelyk Fradenburg (2009:87-115) se oorsig van sodanige Mediëvalistieke lesings van Foucault, terwyl Frantzen (1998:117-137) Foucault in 'n Mediëvalistieke lesing verkwalik vir " Mediëvalisme wat merkwaardig is slegs in terme van 'n gebrek aan detail en 'n Medievvalisme wat merkwaardig is slegs in terme van " $n$ gebrek aan detail en " $n$ nonchalante houding ten opsigte van die relevante dokumente en die nuanses daarin' (Frantzen 1998:7). In 'n (onbedoelde) Mediëvalistieke lesing van Foucault se resepsie van die Middeleeue, kom die skrywer (Beukes 2019:1-5) egter tot ' ander slotsom, naamlik dat Foucault se hantering van sy Middeleeuse bronne (veral die notules van konsilies en die relevante strafkodekse) getuig van sowel 'n deurtastende (bykans skolastiese) ontledingsvermoë as die sonderlinge talent om sinteties telkens weer bo daardie bronne uit te styg. bestaande Middeleeuse spesialisnavorsing, as van tendense in kontemporêre (kontinentale) filosofie. Hierdie opgaaf is nie langer te versoen met 'n 'sekondêre' en 'nie-outentieke' taakstelling (vis à vis Middeleeuse Studies) nie - juis nie in die beeldgemedieerde 21 ste eeu nie.

In Mediëvalistiek bestaan daar dus 'n sonderlinge nadruk op die verhouding tussen diskoersanalitiese navorsing en 'kreatiewe' benaderings tot die Middeleeue. 'n Laaste oorweging by die tref van kritiese onderskeide en samehange tussen Middeleeuse Studies en Mediëvalistiek is, gegewe hierdie Mediëvalistieke verhouding tussen historiese navorsing en kunstige projeksie, die werklikheid dat die historiese dissiplines, veral in Filosofie, eietyds met die rug teen die muur te staan gekom het (vgl. Beukes 2020c:1-3). Antieke Filosofie, Middeleeuse Filosofie en Renaissancefilosofie word toenemend uit filosofiedepartemente se leerplanne by universiteite wêreldwyd geweer, terwyl Analitiese Filosofie (veral Wittgenstein-studies) veld bly wen en opkomende dissiplines in kontinentale filosofie dinamies vooruitgaan, veral met verwysing na die dramatiese opkoms van Tegniekfilosofie die afgelope twee dekades. ${ }^{16}$ Die soepelheid van Mediëvalistiek as genre (deur byvoorbeeld van filmgrepe en fiktiewe uitsette in die onderrig van Middeleeuse filosofie gebruik te maak), asook die kritiese evaluering van die eietydse filosofiese resepsie van die Middeleeue (soos by Lacan en Foucault), lewer, ironies genoeg, 'n betekenisvolle bydrae om Middeleeuse Studies as sodanig lewendig te hou.

Na die skrywer se doseerervaring verkies selfs nagraadse studente toenemend om vanuit 'n verskeidenheid genres in Middeleeuse Filosofie onderrig te word - en nie slegs vanuit teksgebaseerde lesings in Latyn of ontledings van die gespesialiseerde tekste alleen nie. Fiksies soos The Name of the Rose en The Pillars of the Earth, met die duidelike Mediëvalistieke strekking en inhoud daarvan (synde post-Middeleeuse resepsies van die Middeleeue wat die Middeleeue nie-gespesialiseerd reflekteer), beskik oor die vermoë om studente wat die uitsluitlike eksegese van Middeleeuse tekste en temas vervreemdend vind, nader aan die dissipline te trek en naby daaraan te hou. Deur hierdie Mediëvalistieke (niegespesialiseerde) uitsette as geleiers in 'n leerplan te implementeer, word die indruk gerelativeer dat Middeleeuse Studies antikwaries en hoogstens 'n (luukse) geleentheidsbelangstelling in die groter vakgebied Filosofie is maar ook juis as eietyds relevant aangedui (Beukes 2020c:8-12).

\section{Mediëvalistiek en Mediëvalisme: Kritiese onderskeide en samehange}

Die legitimiteit van Mediëvalistiek - na bostaande betoog - as 'n geldige ideologiekritiese aanvulling tot Middeleeuse Studies word tot hoogste uitdrukking gebring in die deeldissipline se

16.'n Onlangse (en tipiese) voorbeeld van die agteruitgang van die historiese dissiplines in filosofie (teenoor die vooruitgang van analitiese filosofie en tegniekfilosofie) kan gevind word in die konferensieprogram van Nederlandse tegniekfilosofie) kan gevind word in die konferensieprogram van Nederlandse Onderzoeksschool Wijsbegeerte, (weens Covid-19) aanlyn gehou op 11 en 12 Desember 2020 by Tilburg Universiteit, Nederland. Uit die 60 voordragte wat by die konferensie gedien het (oorwegend deur Ph.D.-kandidate), was daar nie ' enkele bydrae vanuit die historiese dissiplines nie. Afgesien van ' $n$ halfuur lange 'kamerontmoeting' (History Chamber Meeting op 11 Desember 2020, 12:45-
$13: 45$ ), was die geskiedenis van filosofie geheel en al afwesig by hierdie hoogs prominente Nederlands-Belgiese konferensie. 
vermoë om Mediëvalisme te identifiseer en teen te gaan. Omdat ideologies reduksionistiese en anachronistiese herkonstruksies van die Middeleeue ná die 15de eeu refreinmatig voorgekom het in die Westerse ideëgeskiedenis (cf. Biddick 1998:1-10), waarvolgens die Middeleeue deur die essensialisering van een of meer kontingente met gevolglike karikaturisering voorgestel is, behoort die kritiese ontmaskering van die ideologiese grondslae van Mediëvalisme as Mediëvalistiek se mees uitdruklike opgaaf aangedui te word (cf. Patterson 1987:70-74). Mediëvalisme word sodoende juis ideologiekrities ontbloot as die post-Middeleeuse opstelling van 'n Middeleeuse 'Ander' ter wille van die bestendiging van 'n tydgenootlike 'Self' en as die spontane postulering van die dispariteit tussen sodanige meerderwaardige Self en 'n ondergeskikte Middeleeuse Ander (cf. Prendergast \& Trigg 2009:124).

Mediëvalistiek aanvaar as 'n basiese vertrekpunt dat die Middeleeue reeds sedert die aanbreek van die Italiaanse Renaissance in die laaste dekades van die 15 de eeu sowel ' $n$ 'navorsingsruimte' as 'n 'ruimte vir fantasie' was (Petersen 2011:36). In dieselfde mate wat gepoog is om die Middeleeue wetenskaplik deur (post-Middeleeuse) Middeleeuse Studies oop te dek, het die ideologisering van die Middeleeue momentum gekry. Reeds sedert die Renaissance is die Middeleeue soveel bedink as wat dit verbeel is en soveel ontleed as wat dit verkunstig is. Tog is 'n rigiede onderskeiding tussen denke en verbeelding binne historieswetenskaplike konteks misplaas: hoewel Middeleeuse Studies as 'n versameling historiese dissiplines op die 'feitelike' en 'wetenskaplik verifieerbare' inhoud van die Middeleeue fokus en aanspraak maak op 'n 'geldige kennis' van die Middeleeue, kan dit nie ontkom aan die (ideologiese) strewe na 'outentisiteit' nie. Die resultate van historiese en wetenskaplik verantwoorde ondersoeke word immers met erns as 'akkuraat' voorgestel: wie ist es eigentlich gewesen. Die wetenskaplike kenmerking van die Middeleeue in omvangryke histories-kritiese ondersoeke, soos in R.W. Southern se The Making of the Middle Ages (1992), N.F. Cantor se The Civilization of the Middle Ages (1994), of J. Le Goff se meer onlangse The Birth of Europe (2006), maak natuurlik nie aanspraak op ' $n$ volkome verstaan van die Middeleeue nie maar dring wel aan op die korrektheid van dit wat na hierdie ondersoeke die Middeleeue 'in wese' sou gekonstitueer het.

Dit is egter 'n 'akkuraatheid' wat histories nooit finaal geverifieer kan word nie en uiteindelik nie minder op die verbeelding en 'geloof' (in die wetenskap) aangewese is as wat estetiese projeksies van die Middeleeue op 'verbeelding' aangewese is nie. Die historiese wetenskappe is in hierdie aandrang op 'akkuraatheid' en 'outensiteit' altyd self tot genuanseerde mate ideologies: dit is uiteindelik idees wat telkens per Vorhabe, Vorsicht en Vorgriff die toets vir die korrektheid en outentisiteit aangaande die Middeleeue bemoontlik. 'Geskiedenis', anders gestel, moet soveel geglo as bewys word - aangesien geen bewys van dit wat was finaal en afdoende kan wees nie. Dit wat was, is immers nie meer voorhande nie. 'Geskiedenis' is ten diepste 'n abstraksie - en daarom aangewese op ('n dinamiese subjek-objek/subjek, dit is 'n hermeneutiese) interpretasie.

Tog moet hierdie onafwendbare element van subtiele ideologisering in die historiese wetenskappe onderskei word van die brute ideologisering van die Middeleeue in Laat Moderne Mediëvalisme. Hier is nie 'n delikate, onafwendbare ideologiese waarheidsbegrip werksaam soos aanmerkbaar in die historiese wetenskapsbegrip nie: in Laat Moderne Mediëvalisme word pejoratiewe (onder meer blatant rassistiese; cf. Brown 2000:547-548), patroniserende (veral homofobiese; cf. Beukes 2020d:1-3; Brown 2000:549) en vals godsdienstige karikature (byvoorbeeld ten opsigte van Middeleeuse Islam; cf. Holsinger 2007:30-82) vanuit amateuragtige (maar wydverspreide) lesings oor die Middeleeue met reëlmaat aangebied. So skadelik as wat 'n tipiese Renaissancistiese Mediëvalisme ('in die middel', 'donker' en 'wreed') vir 'n post-Middeleeuse verstaan van die Middeleeue ook al was, en so misplaas verheerlikend die Victoriaanse Mediëvalisme vanuit die 19de eeu (synde 'meer ridderlik' en 'meer maagdelik') ook al steeds is, is die Mediëvalismes in die ideëgeskiedenis self ontmantel as feitelik nie korrek nie. Geen belese mens kan enige van hierdie twee Mediëvalismes langer as 'waar' aanvaar nie: wel moontlik as fantasie en wensdenkery, maar nie as 'waar' nie.

Daar is egter 'n veel ernstiger soort Mediëvalisme waarteen Mediëvalistiek eietyds in ideologiekritiese gerig behoort te kom, naamlik die toksiese kombinasie van Neokonserwatisme en Mediëvalisme. Die essensialiserende en reduksionistiese 'resepsie' van die Middeleeue in Neokonserwatiewe kringe (juis binne die hoogste uitvoerende gesag) van die Verenigde State sedert 2001 (met inbegrip van die komies tragiese Trump-impasse vanaf Januarie 2017 tot Januarie 2021) is hiervan 'n duidelike voorbeeld. Ná die aanvalle op New York, Washington en Amerikaanse lugruim op 11 September 2001, is die selferkende protagoniste vir die aanvalle, alQaeda en die (veronderstelde) regsubjek Osama bin Laden, uitermate gou gekarikaturiseer as die 'slinkse Muslims reeds vanaf die kruistogte' (Holsinger 2007:30). Die tweede Bushadministrasie (20 Januarie 2001 - 20 Januarie 2009) se gevolglike 'Oorlog teen terreur' (War on Terror) op grond waarvan ' $n$ tweede oorlog binne net meer as 'n dekade teen Irak (2003-2011) van gestapel gestuur is, het nie bloot die deursigtige leuen van 'wapens van massavernietiging' (weapons of mass destruction) in die gewaande 'kernarsenale' van Saddam Hussein as regverdiging vir die oorlog aangebied nie. Die oorlog is ideologies geregverdig deur die postulering van (sowel Shia as Sunni) Islam as 'n onvoorspelbare, bedrieglike 'Middeleeuse Ander', spontaan ondergeskik aan en daarom 'n konstante bedreiging vir die meerderwaardige, stabiele Westerse Self.

Neokonserwatisme se dubbel ideologiese simbiose met Mediëvalisme het geblyk 'n effektiewe, maar dodelike kombinasie te wees: Donald Rumsfeld (die Verenigde State se Sekretaris van Verdediging, 2001-2006) en die toemalige president George W. Bush se kru Mediëvalisme(s) kan 
teruggevind word in herhaalde selfregverdigende verwysings na die oorlog as 'n 'Middeleeuse kruistog' en die regstreekse tipering van die War on Terror as 'n crusade ofte wel, kruisvaart. So beweer Rumsfeld, onder meer, dat die 'vyand' (sonder enige nuanse of aanvoeling vir die onderskeid tussen Shia en Sunni Islam) ...

... reeds vanaf die Middeleeue die vermoë gehad het om te vermeng en aan te pas in vreemde kulture, vinnig oor grense te beweeg, aan te val en dan weg te kruip. (Holsinger 2007:52)

'Middeleeuse Islam', na hierdie Mediëvalistiese en Anderskeppende jargon, was 'effektiewelik 'n transnasionale terreurorganisasie' wat 'reeds vanaf die Middeleeue 'n veelheid van middele gebruik het om terreur te saai' (Holsinger 2007:52).

In'nuitstaandeMediëvalistieke, ideologiekritiese ontmaskering, ontbloot B. Holsinger in sy Neomedievalism, Neoconservatism, and the War on Terror (2007) sistematies nie alleen die geweldstigtende aard van dié kombinasie van Neokonservatisme en Mediëvalisme nie: hy dui ook met presisie aan hoe Mediëvalisme as ' $n$ 'spesifieke intellektuele meganisme' binne die 'Neokonserwatiewe politieke diskoers in geheel na 2001 ontplooi is' (Holsinger 2007:82). Trouens, Neokonserwatiewe politieke beleid is aangepas om in die voeë van hierdie Mediëvalisme in te val - en nie andersom nie. Dié Mediëvalisme is dus nie geplooi om by politieke beleid aan te pas nie: so effektief is die Mediëvalisme ingespan dat die politieke beleid vanaf 2003 tot 2011 (ook steeds ná Rumsfeld se bedanking in 2006) uitdruklik daarop geskoei was (Holsinger 2007:82-90). Holsinger se werk verteenwoordig die beste waartoe eietydse Mediëvalistiek in staat is en kan wees. Hoewel hy nie 'n Middeleeuse spesialis is nie, is hy belese genoeg om aan te sluit by Middeleeuse Studies om die tragies ideologiese karikature van Middeleeuse Islam binne Neokonserwatiewe kringe te identifiseer en krities teen te gaan.

Neokonserwatiewe Mediëvalisme, na Holsinger se ontleding, funksioneer as die perfekte retrospektiewe bloudruk vir wat Mediëvalisme reeds vanaf die tweede helfte van die 15 de eeu was: die opstel van 'n Middeleeuse Ander ter wille van die bestendiging van die belange (veral kultureel, ekonomies en militêr) van 'n tydgenootlike Self, die ontwikkeling van 'n karikatuur en die spontane postulering van ' $n$ dispariteit tussen die sodanige meerderwaardige Self en die ondergeskikte Middeleeuse (of vanuit die Middeleeue gekonstrueerde) Ander. Holsinger se werk kan daarom as 'n uitstekende eietydse voorbeeld van die kritiese onderskeide en samehange tussen Mediëvalistiek en Mediëvalisme aangebied word. Die legitieme aanspraak van Mediëvalistiek as 'n ideologiekritiese aanvulling tot Middeleeuse Studies word in sy werk duidelik gestempel.

\section{Samevatting en konklusie}

Hierdie artikel het in aansluiting by die skrywer (Beukes 2020a:3,12-14, 2020b:1-6, 2021a:1-6) se drieledige aanduiding van eietydse navorsinguitdagings in Middeleeuse Filosofie gepoog om Mediëvalisme as 'n bykomende uitdaging in die meer algemene vakraamwerk van Middeleeuse Studies te stel. Deur kritiese onderskeide en samehange tussen Middeleeuse Studies, Mediëvalistiek en Mediëvalisme uit te wys, is sistematies betoog dat Mediëvalistiek as 'n geldige ideologies kritiese toevoeging tot Middeleeuse Studies aanvaar behoort te word. Die geldigheid hiervan is geillustreer deur verwysing na die ideologiekritiese ontbloting van die problematiese kombinasie van Neokonserwatisme en Mediëvalisme.

Die tyd vir vak-elitistiese vooroordele teenoor Mediëvalistiek is onherroeplik verby. In die 21ste eeu het Mediëvalistiek nie alleen ' $n$ geldige plek binne Middeleeuse Studies nie, die ideologiekritiese en genre-soepele vermoë van Mediëvalistiek dui op 'n deeldissipline wat onontbeerlik geword het in die ontmaskering van post-Middeleeuse karikaturiserings van en rondom die Middeleeue, juis in eietydse ideologiese vergrype aan 'dit wat was'. Dat hierdie kritiese besinning oor die Middeleeue ook in fiksie, film en welke ander genres ook al onderneem kan word, is 'n wins vir Middeleeuse Studies en nie 'n verleentheid nie.

\section{Erkenning}

Die skrywer is ook verbonde aan die Sentrum vir die Geskiedenis van Filosofie en Wetenskap (CHPS) aan Radboud Universiteit Nijmegen, Nederland.

\section{Mededingende belange}

Die skrywer verklaar dat hy geen finansiële of persoonlike verbintenis het met enige party wat hom nadelig kon beïnvloed in die skryf van hierdie artikel nie.

\section{Outeursbydrae}

J.B. was die enigste skrywer van hierdie artikel.

\section{Etiese oorwegings}

Hierdie artikel volg alle etiese standaarde vir navorsing sonder direkte kontak met mens of dier.

\section{Befondsing}

Die artikel is befonds deur die Departement Filosofie \& Klassieke, Fakulteit Geesteswetenskappe, Universiteit van die Vrystaat.

\section{Data beskikbaarheidsverklaring}

Data-deling is nie van toepassing op hierdie artikel nie, aangesien geen nuwe data in hierdie studies geskep of ontleed is nie.

\section{Vrywaring}

Die sienings en menings wat in hierdie artikel uitgedruk word, is dié van die skrywer en weerspieël nie noodwendig die amptelike beleid of posisie van enige geaffilieerde agentskap van die skrywer nie. 


\section{Literatuurverwysings}

Adamson, P. \& Pormann, P.E. (reds. \& vert.), 2012, The philosophical works of Al-Kindi, Oxford University Press, Oxford.

Aers, D., 1992, 'Medievalists and deconstruction: An exemplum', in J. Simons (red.), From Medieval to Medievalism, bl. 24-40, Macmillan, Londen.

Beukes, J., 2018a, 'Die Arabiese trajek in die Karolingiese periode in Middeleeuse filosofie', Litnet Akademies 15(3), 502-564, besigtig 06 Maart 2021, vanaf https:// www.litnet.co.za/wp-content/uploads/2018/12/LitNet_Akademies_15-3 www.litnet.co.za/wp
Beukes_502-564.pdf.

Beukes, J., 2018b, 'Die Arabiese trajek in die post-Karolingiese periode in Middeleeuse filosofie', Litnet Akademies 15(3), 565-626, besigtig 06 Maart 2021, vanaf https:// www.litnet.co.za/wp-content/uploads/2018/12/LitNet_Akademies_15-3 Beukes_565-626.pdf

Beukes, J., 2019, “"Foucault se sodomiet”: Damianus se Liber gomorrhianus (1049) heropen', HTS Teologiese Studies/Theological Studies 75(4), Art. \#5216, 1-13. https://doi.org/10.4102/hts.v75i4.5216

Beukes, J., 2020a, Middeleeuse Filosofie, Vol. I \& II, Akademia, Pretoria.

Beukes, J., 2020b, 'The Dominican Robert Kilwardby (ca.1215-1279) as schoolman and ecclesiastical official', Verbum et Ecclesia 41(1), Art. \#2065, 1-14. https://doi. org/10.4102/ve.v41i1.2065

Beukes, J., 2020c, 'Sensus communis: The relevance of Medieval philosophy in the 21st century', HTS Teologiese Studies/Theological Studies 76(4), Art. \#5937, 1-13. https://doi.org/10.4102/hts.v76i4.5937

Beukes, J., 2020d, 'Intervroulike seksualiteit in die latere Middeleeue: 'n Ideëhistoriese oorsig', Verbum et Ecclesia 41(1), Art. \#2074, 1-13. https://doi.org/10.4102/ ve.v41i1.2074

Beukes, J., 2021a, 'The case for post-scholasticism as an internal period indicator in Medieval philosophy', HTS Teologiese Studies/Theological Studies 77(4), Art. \#6270, 1-12. https://doi.org/10.4102/hts.v77i4.6270

Beukes, J., 2021b, 'Besinning oor filosofie in die kloostermistieke teks Hortus Deliciarum (ca.1185) deur Herrada Landsbergensis (ca.1130-1191)', Verbum et Ecclesia 42(1). (In publikasie).

Beukes, J., 2021c, 'Neoplatonism in the Cologne tradition of the later Middle Ages: Berthold of Moosburg (ca.1300-1361) as case study', HTS Teologiese Studies/ Theological Studies 77(1), Art. \#6281. https://doi.org/10.4102/hts.v77i4.6281

Biddick, K., 1998, The shock of Medievalism, Duke University Press, Durham.

Brown, C., 2000, 'In the middle', Journal of Medieval and Early Modern Studies 30(1) 547-574. https://doi.org/10.1215/10829636-30-3-547

Cantor, N.F., 1994, The civilization of the Middle Ages, Harper Perennial, New York, NY.

Eco, U., [1980] 2006, 'The name of the rose', in D. Lodge (inl.), W. Weaver (vert.) Penguin Random House, New York, NY.

Eco, U., 1986, Travels in hyper-reality, vert. W. Weaver, Harcourt, San Diego, CA.
Fitzpatrick, K., 2011, '(Re)producing (Neo)medievalism', in K. Fugelso (red.), Studies in Medievalism XX 2011, bl. 11-20, D.S. Brewer, Cambridge.

Follett, K., 1989, The pillars of the earth, Penguin, Londen.

Fradenburg, A., 2009, '(Dis)continuity: A history of dreaming', in E. Scala \& S. Federico (reds.), The post-historical Middle Ages, bl. 87-115, Palgrave Macmillan, Hampshire.

Frantzen, A., 1998, Before the closet: Same-sex love from Beowulf to Angels in America, University of Chicago Press, Chicago, IL.

Green, R., Evans, M., Bischoff, C. \& Curschmann, M. (reds.), 1979a, Hortus Deliciarum of Herrad of Hohenbourg, Volume I, Commentary, Brill, Leiden.

Green, R., Evans, M., Bischoff, C. \& Curschmann, M. (reds.), 1979b, Hortus Deliciarum of Herrad of Hohenbourg, Volume II, Reconstruction, Brill, Leiden.

HBO, 2011-2019, Game of thrones, seisoen 1-8, episode 1-73.

Holsinger, B., 2007, Neomedievalism, Neoconservatism, and the War on Terror, Prickly Paradigm Press, Chicago, IL.

Ingham, P.C., 2009, 'Amorous dispossessions: Knowledge, desire, and the poet's dead body', in E. Scala \& S. Federico (reds.), The post-historical Middle Ages, bl. 13-35, Palgrave Macmillan, Hampshire.

Labbie, E.F., 2006, Lacan's Medievalism, University of Minnesota Press, Minneapolis, MN. Le Goff, J., 2006, The making of Europe, Wiley-Blackwell, Hoboken, NJ.

Lewis, C.S., 1950-1956, The chronicles of Narnia, Vol. I-VII, HarperCollins, Glasgow.

Martin, G.R.R., 1996-2011, A song of ice and fire, Vol. I-V, Random House (Bantam Books), New York, NY.

Patterson, L., 1987, Negotiating the past: The historical understanding of Medieval literature, University of Wisconsin Press, Madison, WI.

Petersen, N.H., 2011, 'Medieval resurfacings, old and new', in K. Fugelso (red.), Studies in Medievalism XX 2011, bl. 35-20, D.S. Brewer, Cambridge.

Prendergast, T. \& Trigg, S., 2009, 'The negative erotics of Medievalism', in E. Scala \& S. Federico (reds.), The post-historical Middle Ages, bl. 117-138, Palgrave Macmillan, Hampshire.

Roden, F.S., 2001, 'Medieval religion, Victorian homosexualities', in C.A. Simmons (red.), Medievalism and the quest for the 'real' Middle Ages, bl. 115-130, Frank Cass, Londen.

Shepherd, J., 2016, 'Game of thrones season 6 ratings: Show brought in 25.1 million viewers on average per episode', The Independent, 19 July 2016, besigtig 14 Desember 2020, vanaf https://www.independent.co.uk/arts-entertainment/ tv/news/game-of-thrones-season-6-ratings-show-brought-in-251-millionviewers-on-average-per-episode-a7144261.html.

Southern, R.W., 1992, The making of the Middle Ages, Yale University Press, New Haven, CT.

Tolkien, J.R.R., [1954] 2014, The lord of the rings, Vol. I-III, HarperCollins, Glasgow. 